\title{
Biting Indices, Host-seeking Activity and Natural Infection Rates of Anopheline Species in Boa Vista, Roraima, Brazil from 1996 to 1998
}

\author{
Adenildo da Silva-Vasconcelos, Márcio Yukió Neves Kató, Eliana Neves Mourão, \\ Raimundo Tadeu Lessa de Souza*, Raimundo Nonato da Luz Lacerda*, Alexander Sibajev, \\ Pantelis Tsouris, Marinete Marins Póvoa*, Hooman Momen*:, \\ Maria Goreti Rosa-Freitas
}

\begin{abstract}
Núcleo Avançado de Vetores, Convênio Fiocruz-UFRR, Medicina, CCBS, Campus do Paricarana, Boa Vista, RR, Brasil
*Seção de Parasitologia, Instituto Evandro Chagas, Funasa, Belém, PA, Brasil **Departamento de Bioquímica e Biologia Molecular ***Laboratório de Transmissores de Hematozoários, Departamento de Entomologia, Instituto Oswaldo Cruz-Fiocruz, Av. Brasil 4365, 21045-900 Rio de Janeiro, RJ, Brasil
\end{abstract}

The epidemiology of the transmission of malaria parasites varies ecologically. To observe some entomological aspects of the malaria transmission in an urban environment, a longitudinal survey of anopheline fauna was performed in Boa Vista, Roraima, Brazil. A total of 7,263 anophelines was collected in human bait at 13 de Setembro and Carana districts: Anopheles albitarsis sensu lato (82.8\%), An. darlingi (10.3\%), An. braziliensis (5.5\%), An. peryassui (0.9\%) and An. nuneztovari (0.5\%). Nightly $12 \mathrm{~h}$ collections showed that An. albitarsis was actively biting throughout the night with peak activities at sunset and at midnight. An. darlingi bit during all night and did not demonstrate a defined biting peak. Highest biting indices, entomological inoculation rates and malaria cases were observed seasonally during the rainy season (April-November). Hourly collections showed host seek activity for all mosquitoes peaked during the first hour after sunset. An. darlingi showed the highest plasmodial malaria infection rate followed by An. albitarsis, An. braziliensis and An. nuneztovari $(8.5 \%, 4.6 \%, 3 \%$ and 2.6\%, respectively). An. albitarsis was the most frequently collected anopheline, presented the highest biting index and it was the second most frequently collected infected species infected with malaria parasites. An. albitarsis and An. darlingi respectively, are the primary vectors of malaria throughout Boa Vista.

Key words: Anopheles - biting index - infection rates - malaria - Roraima - Brazil

Malaria continues to be the most important endemic disease in Brazil. Approximately 500,000 cases, primarily in the Amazon Basin (99\%), have been reported annually during the last decade (Fundação Nacional de Saúde-FNS/ Funasa, Ministry of Health). The majority of cases are reported from the states of Pará and Amazonas (Funasa 2000). However, nowhere does malaria have a greater impact on health than in Roraima, as shown by the record annual parasitic indices, (API) (number of cases/ 1,000) reported for the last five years (150.9 in 1995, 143.3, 1996; 104.9, 1997; 81.6, 1998; 135.8, 1999, FNS 1996, Funasa 2000). For the period January-April 2000, a total of 14,973 cases were reported, approximately $40 \%$ of those registered in 1999 (Funasa 2000). Routine inquiries by health authorities provided evidence for the origin of many of the malaria cases (FNS 1996). These investigations showed that people living in small agricultural settlements (37.8\%) and

Supported by the CNPq, Fiocruz, Instituto Evandro Chagas, Funasa, UNDP/World Bank/WHO Special Programme for Research and Training in Tropical Diseases and the Government of the State of Roraima.

This work is part of the doctoral thesis of ASV.

${ }^{+}$Corresponding author. E-mail: goreti@ioc.fiocruz.br

Received 15 March 2001

Accepted 8 November 2001 small villages $(14.6 \%)$ contributed $>50 \%$ of the reported malaria cases. This is an underestimate of the total malaria in the area since may people acquire medication from pharmacies (self-treatment) or private doctors and are therefore not reported. During 1996, malaria cases among native Indians represented $16.5 \%$ of the total, whereas people living in periurban areas accounted for $<15 \%$ (FNS 1996). Approximately $50 \%$ of the mortality (causa mortis) among native Indian populations were accredited to falciparum malaria (FNS 1996).

Vector control is still one of the most successful ways of controlling malaria (WHO 1991). The identification of entomological variables in different malaria areas, such as the prevalent species, density, seasonal variation, larval habitats and infection rates, may assist in the development of effective malaria control programs. Those programs should take into account the way and time to interfere in the transmission cycle to increase effectiveness.

Our objectives were to identify anopheline species, their peak of biting activity, biting indices and natural infection rates and, to collect meteorological data aiming to understand the malaria ecology in the area. Longitudinal studies were conducted in two urban districts in Boa Vista, Roraima, where malaria rates were the highest during 1995: 13 de Setembro (May 1996 to April 1998) and Caranã (June 1997 to April 1998) (FNS 1996). This is the first longitudinal study on malaria vectors performed in the State of Roraima. 


\section{MATERIALS AND METHODS}

Study site - To observe malaria transmission in a highly endemic urban area, anopheline human-bait collections were conducted at Boa Vista (02 49 ' $\left.11^{\prime \prime} \mathrm{N}, 60^{\circ} 40^{\prime} 24^{\prime \prime} \mathrm{W}\right)$, State of Roraima, Brazil, from May 1996 through April 1998. The study was performed in the districts of 13 de Setembro (May 1996 to April 1998) and Caranã (June 1997 to April 1998). These two districts are situated along river margins and had the highest number of reported malaria rates for Boa Vista (from 1970 to 1996, FNS 1997).

Roraima is the northernmost state of Brazil (Fig. 1). Roraima has $225,116 \mathrm{~km}^{2}$ with a population of 254,499 (IBGE 1996). Roraima's rural population density is $<1 / \mathrm{km}^{2}$, while the population density of its capital, Boa Vista, is approximately $27 / \mathrm{km}^{2}(154,000$ people or $62 \%$ of the state population, IBGE 1996, FNS 1998). Approximately $85 \%$ of Roraima is forested, with the remaining $15 \%$ covered by savanna (Silva 1993) (Fig. 1). The climate is tropical humid with mean temperatures $27.8^{\circ} \mathrm{C}$ (range 27.3 to $28.9^{\circ} \mathrm{C}, 10$ years) and mean rainfall $429 \mathrm{~mm}$ (range $391 \mathrm{~mm}$ to $451 \mathrm{~mm}$, 4 years) with low annual variation (NASA 2001).

Savanna is the predominant ecological environment in Boa Vista. The climate presents two distinct seasons; a rainy season between April and November with high rainfall indices during the months of June and July (Schmidt 1942). The Branco River crosses the city in the northwestern direction (Fig. 2). During the driest months (December-March) the Branco River margins are intensely exploited for brick manufacturing. All the manufacturing

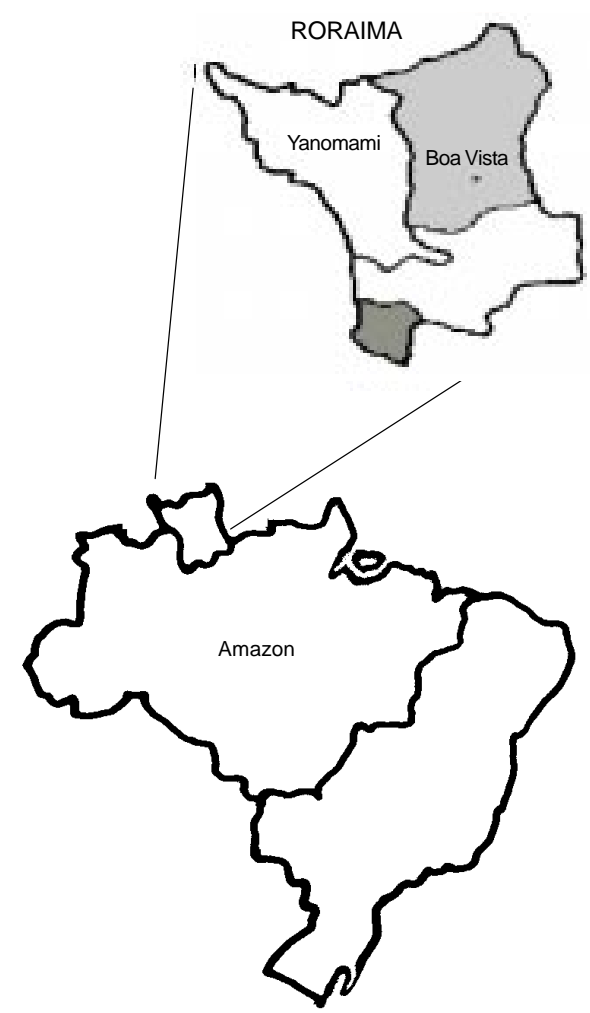

Fig. 1: Brazil, expanded area, Roraima. Light gray, savana; dark gray, equatorial forest with predominance of várzeas and igapós (permanent and semi-permanent flooded areas); white equatorial forest with predominance of non-flooded areas (IBGE 1992) processes are manual and locally made, from clay extraction to molding, burning and sales. This makes a floating population of around 3,000 people that to move to the Branco River margins, some with their families living in huts without walls at 13 de Setembro. The daily excavation of clay produces shallow pits (2-3 $\mathrm{m}$ depth, $\sim 3 \mathrm{~m}$ diameter) where water accumulates. Even though $\mathrm{NaOH}$ (used in brick manufacturing), is washed into those pits, we decided to check whether they could be providing breeding sites for anophelines.

The district of 13 de Setembro, with 12,000 inhabitants, is situated southeastern of Boa Vista (Fig. 2). Besides Branco River, another smaller stream, the Pricumã Igarapé, borders the district together with dense marginal vegetation. This dense vegetation in combination with pools and slow moving waters provide suitable habitats for many anopheline mosquitoes. The district of 13 de Setembro accounts for the highest number of reported malaria cases in Boa Vista (1970 to 1996, FNS 1997).

The district of Caranã, with 10,800 inhabitants, is located in western Boa Vista at the margin of a large permanent stream, the Cauamé Igarapé (IBGE 1996) (Fig. 2). While no longer active, there was evidence of clay exploitation for brick manufacturing along the margins of the Cauamé. From this exploitation, shallow pools that could provide suitable habitats for mosquitoes were formed. Caranã district had the second highest number of reported malaria cases in Boa Vista (FNS 1997).

Selected entomological variables investigated were seasonal and hourly biting indices and natural infection rate for the various anopheline species. The suitability of the brick pools for anopheline habitats were also checked in 13 de Setembro. Meteorological and reported human malaria cases data were provided by local authorities. Rainfall indices, temperature and humidity averages were those from the Air Force Meteorological Station in Boa Vista. Malaria cases data was obtained from Funasa-RR.

Adult collection - At 13 de Setembro, adult humanbait collections were performed for 7 to 10 consecutive days/month from May 1996 through April 1997 and 1 to 5 consecutive days/month from May 1997 through May 1998. Human-bait collections were performed at dusk (18:00-20:00 $\mathrm{h} \pm 30 \mathrm{~min}$, sunset time variation throughout the year) in a house located $\sim 100 \mathrm{~m}$ from the right margin of the Branco River and $\sim 50 \mathrm{~m}$ from the Pricumã Igarapé, in a neighborhood called Olaria. Collections were done on the veranda of a house with screened windows and doors. People living in this house (a family of 17 members) were previously affected by many malaria episodes. They normally interrupted their outdoors activities by 18:00 h for dinner and TV, a common behavior for the whole neighborhood.

A $12 \mathrm{~h}$ collection, from 18:00 to $06: 00 \mathrm{~h}$, was performed in 13 de Setembro for one of the ten days of the consecutive collection period, from May 1996-April 1997, to determine biting activity peaks.

In Caranã, adult collections were conducted for one to five consecutive days/month (June 1997-April 1998). Human-bait collections also were performed at dusk (18:0020:00 h) on the veranda of a wood-constructed house located approximately $50 \mathrm{~m}$ from the Cauamé Igarapé. 


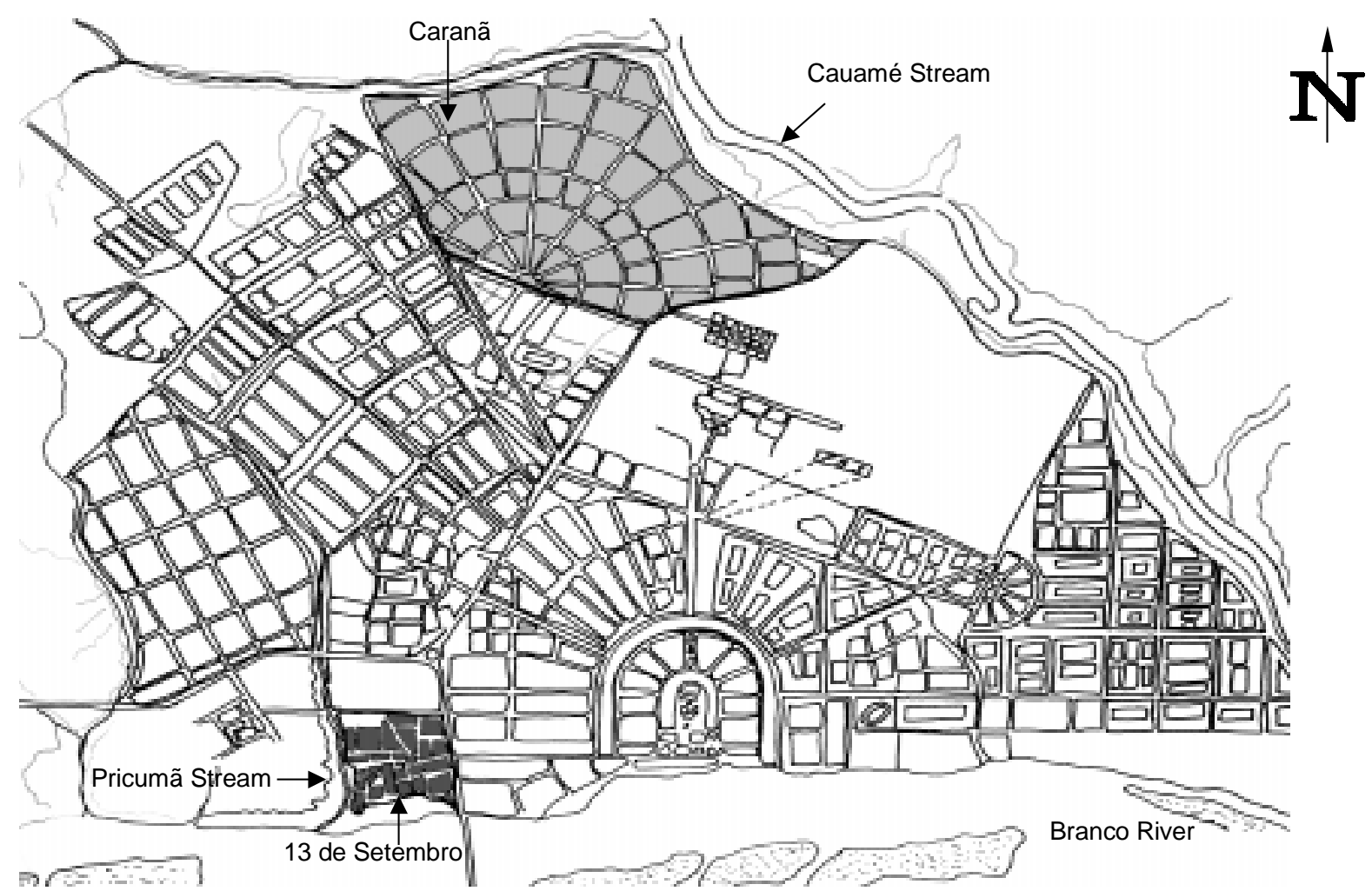

Fig. 2: municipality of Boa Vista, Roraima, with the districts of 13 de Setembro and Caranã, Branco and Cauamé rivers and Pricumã Igarapé.

Anopheline species were identified using taxonomic keys (Consoli \& Lourenço-de-Oliveira 1994). Data were recorded for the number of specimens collected by species, collection time and date, and number of collectors. Biting indices were calculated for Anopheles albitarsis sensu lato (hereafter only An. albitarsis), An. darlingi, An. braziliensis, An. nuneztovari and An. peryassui for the first hour after sunset (18:00-19:00 h) and for An. albitarsis and An. darlingi for the second hour (19:00-20:00 h). The indices were obtained by dividing the number of mosquitoes collected daily by the number of collectors and the hours of collection daily. Monthly means (based on the 510 collections/month) for the $1 \mathrm{st}, 2 \mathrm{nd}$ and for the $2 \mathrm{~h}$ period were also calculated. Mosquitoes were kept in silica-gel for natural malaria infection determination.

Excavation pits as anopheline habitats - Immature collections in the brick shallow pits were performed with $400 \mathrm{ml}$ metallic dippers ladles in the early morning from 06:00-06:30 $\mathrm{h}$ in water flooded excavations $\sim 2 \mathrm{~km}$ along the Branco River margin, at 13 de Setembro. Investigations were performed five days per month during the same period as the adult mosquito collections, whenever the Branco River water level permitted. Larvae and pupae were either placed in $70 \%$ alcohol or reared in the laboratory to 4th instars or to adults, respectively, for identification. Water temperature and $\mathrm{pH}$ were recorded during collections and means calculated. Species identification were as previously described for adults.
Determination of anopheline infection rates - The assays were performed at the Laboratório de Entomologia da Malária, Serviço de Parasitologia, Instituto Evandro Chagas, Belém, Pará. Specimens had their identification reconfirmed based on the same taxonomic key (Consoli \& Lourenço-de-Oliveira 1994). Only the head and prothorax of the specimens were used. An. darlingi, An. nuneztovari and $A n$. peryassui were individually assayed. For $A n$. albitarsis sensu lato and An. braziliensis 5 specimens from the same collection date were pooled per tube.

Methodology used ELISA techniques essentially the same described in Wirtz et al. (1987a,b).

Lyophilized monoclonals antibodies for Plasmodium falciparum, P. vivax VK210, P.vivax VK247 and P. malariae and, positive controls used were kindly provided by Dr Pamela Patterson, National Center for Infectious Diseases, Centers for Disease Control and Prevention-CDC, produced by Kirkegaard \& Perry Laboratories.

Statistics - Results were analyzed by Pearson's correlation coefficient, Student's t test and, standard error of the correlation coefficient (Rodrigues 1993). Pearson's correlation coefficient (r) was used to evaluate the degree of dependence between variables. Student's t test (t) identified significant levels of dependence between variables to determine whether one had an effect on other variables or were related by chance. Significant levels were designated as twice correlation coefficient difference from the correlation coefficient $r$. 


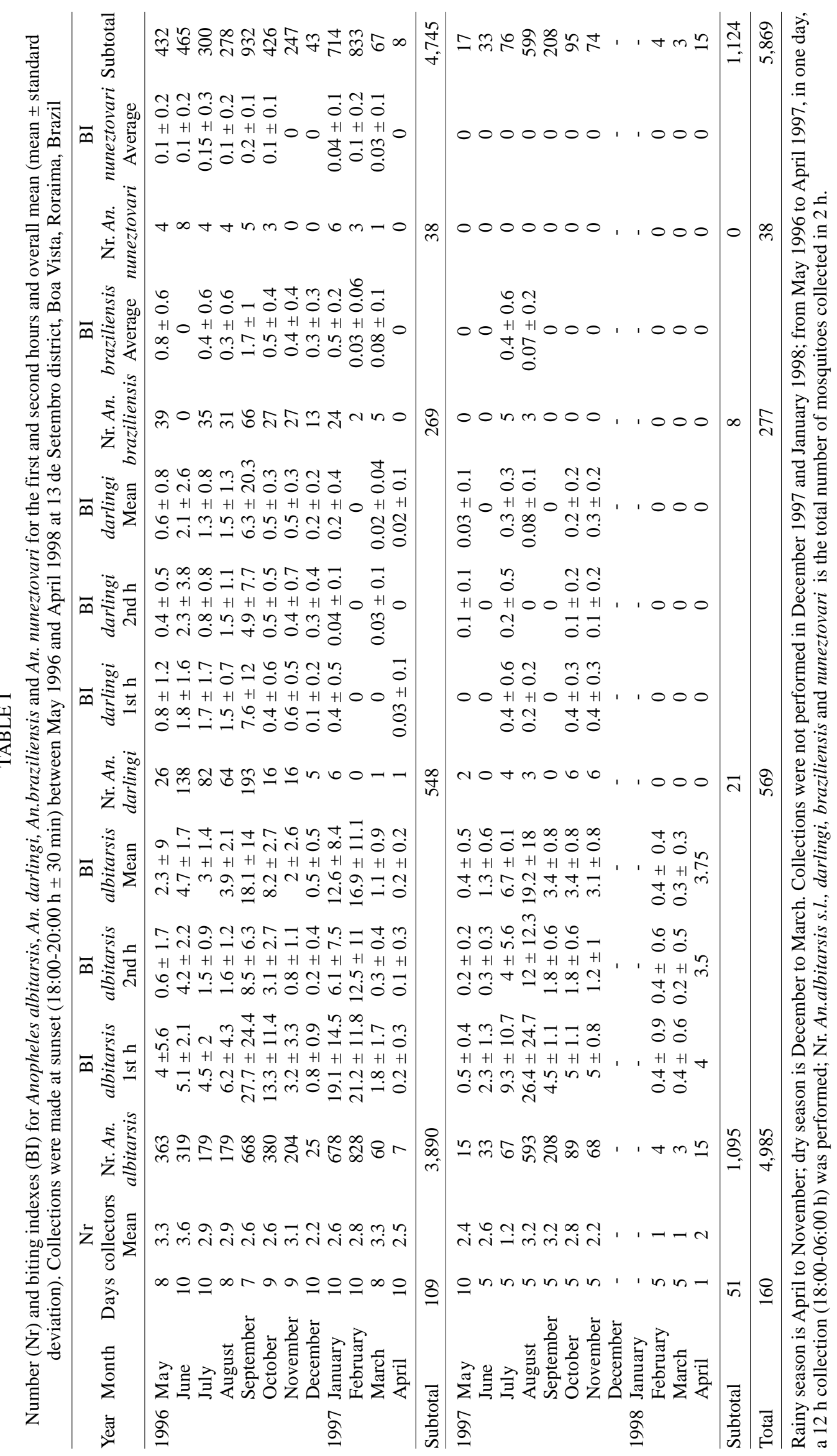




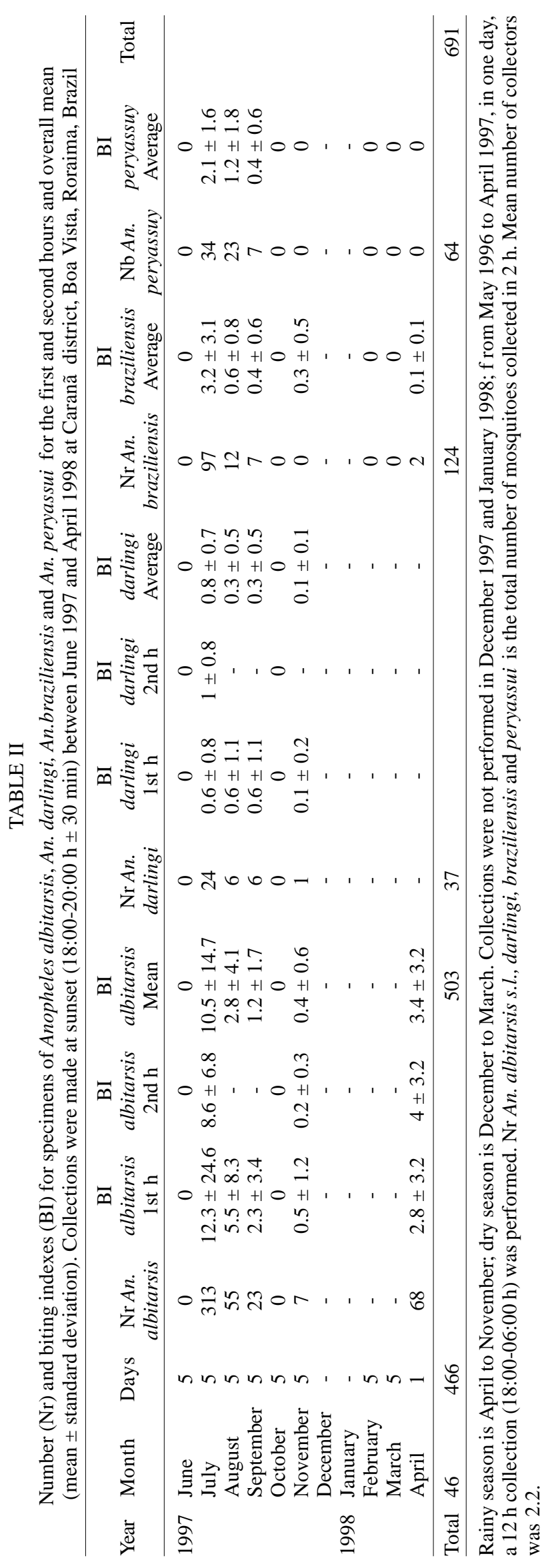

\section{RESULTS}

Adult collections - From May 1996 to April 1998, 7,263 specimens were identified to five species: An. albitarsis (82.8\%), An. darlingi (10.3\%), An. braziliensis (5.5\%), An. peryassui $(0.9 \%)$, and An. nuneztovari $(0.5 \%)$.

The number of collectors/night ranged from 1-6, 2.6 mean, during the study period in 13 de Setembro. In Caranã, the number of collectors/night ranged from 2-3 (mean 2.2). Total man-hours of collection was 1,194 for 13 de Setembro and 110 for Caranã.

Mosquito biting indices (BI) were highest seasonally during the first hour after sunset (18:00-19:00 h) during the rainy season (April-November) at 13 de Setembro district (Tables I, II). At both 13 de Setembro and Caranã districts, An. albitarsis BI, while variable seasonally, were higher than for other anophelines species (as high as 27.7 in September 1996). An. nuneztovari specimens were collected only at 13 de Setembro with BI of $=0.2$ (May-October 1996 and January-March 1997). An.peryassui was collected only at Caranã. An. darlingi, An. braziliensis, An. nuneztovari and $A n$. peryassui were infrequently collected throughout the study at both districts.

To determine host-seeking activity, monthly $12 \mathrm{~h}$ collections (18:00-06:00 h) were performed at 13 de Setembro from May 1996 through April 1997. A total of 1,334 specimens were collected, An. albitarsis (76\%), An. darlingi (21.2\%), An. braziliensis (2.1\%) and An. nuneztovari (0.7\%) (Fig. 3).

An. albitarsis, the most abundant species, was found throughout the night with peaks at sunset (18:00-20:00 h) and during the middle of the night (23:00-02:00 h). These peaks were observed in May and August through November 1996. An. darlingi was found biting throughout the night (May, July, August and November 1996). A biting peak was observed for An. darlingi only in September 1996, when most specimens were collected at sunset. An. braziliensis and An. nuneztovari were present in small numbers, always at sunset.

Immature collections - At 13 de Setembro, a total of 342 immature anopheline specimens were collected during 80 days of collections from irregular excavations along the north margin of Branco River associated with manual brick manufacturing. Species collected were $209 A n$. albitarsis, 17 An. nuneztovari, 17 An. darlingi and 10 An. oswaldoi. An. oswaldoi was found only in this type of collection. Water was turbid, mixed with clay, with temperatures and $\mathrm{pH}$ ranging from $22.7-27.6^{\circ} \mathrm{C}$ and 6-6.5 mean, respectively, during the time of collection, from May 1996 through January 1997 (Table III).

Mosquito natural infection rates - A total of 7,198 specimens were analyzed by ELISA for malaria parasites. Malaria infections were found in 383 anophelines, 31 being mixed infections (MI). An. darlingi had the highest natural infection rate (IR) $(8.5 \%$, excluding MI) followed by An. albitarsis (4.6\%), An. braziliensis (3\%) and An. nuneztovari (2.6\%). An. albitarsis was positive for all plasmodia investigated. An. peryassui was not found infected. Only one An. darlingi specimen was found infected in Caranã (Table IV). IR were calculated monthly as the number of infected specimens among the total analyzed per species (Table V). 
$P$. vivax was the most prevailing plasmodium infecting anophelines $(72.3 \%$, both strains) followed by $P$. falciparum (26.1\%) and P. malariae (1.6\%).

Among the 27 specimens of An. albitarsis with MI, 14 were found with $P$. vivax VK210 and $P$. falciparum, 10 with $P$. vivax VK 210 and P.vivax VK 247 and 3 with $P$. vivax VK 247 and P. falciparum. The 4 specimens of $A n$. darling $i$ with $\mathrm{MI}, 2$ had $P$. vivax VK210 and $P$. vivax VK
247,1 with $P$. vivax VK 210 and $P$. falciparum and 1 with $P$. vivax VK 247 and $P$. falciparum. The other species showed no MI.

Entomological inoculation rates - Entomological inoculation rates (EIR) were calculated monthly as the product of BI and IR (Shiff et al. 1995) (Table V). EIR varied seasonally. An. albitarsis displayed the highest monthly EIR followed by An. darlingi and An. braziliensis.

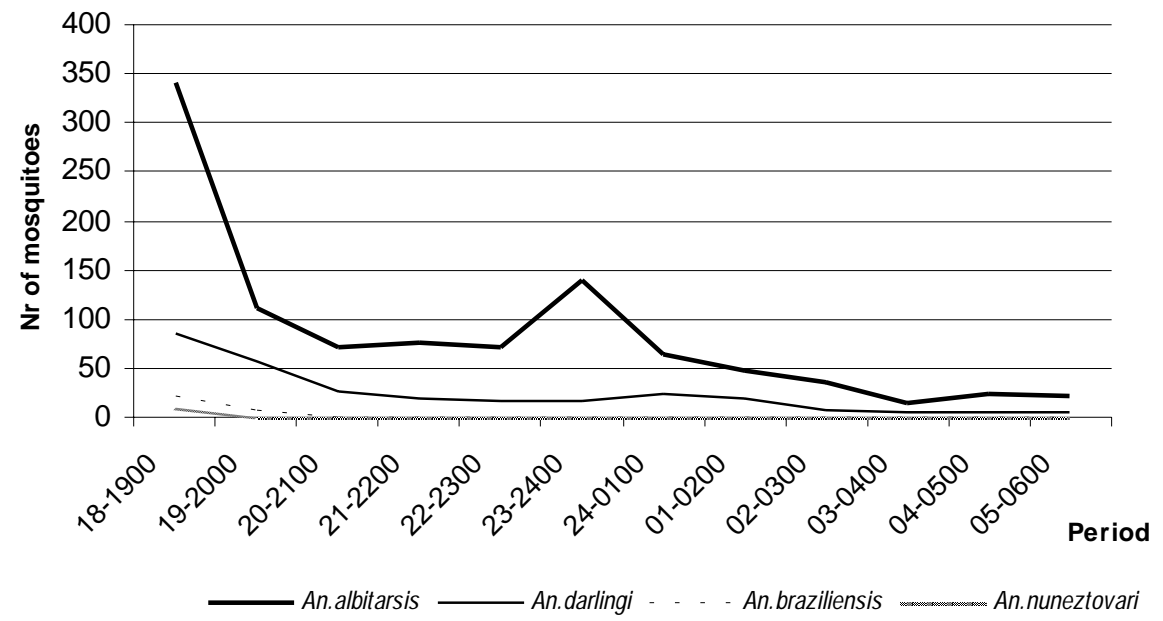

Fig. 3: peak of host seeking activity as expressed by the mean number of mosquito specimens collected per hour during $12 \mathrm{~h}$ collections (18:00-06:00 h) for the period May 1996 to April 1998 in the 13 de Setembro district, Boa Vista, Roraima.

TABLE III

Number of immature anophelines specimens (Nr) collected in excavations at the Branco River margin during May 1996 through April 1998, 13 de Setembro district, Boa Vista, Roraima, Brazil

\begin{tabular}{|c|c|c|c|c|c|c|c|c|c|c|c|}
\hline Year & Month & Days ${ }^{a}$ & $\begin{array}{c}\text { Rainfall } \\
\text { (mm) }\end{array}$ & $\begin{array}{c}\text { Temperature } \\
\left({ }^{\circ} \mathrm{C}\right)\end{array}$ & $\begin{array}{c}\text { Water } \\
\text { temperature } \\
\left({ }^{\circ} \mathrm{C}\right)\end{array}$ & $\mathrm{pH}$ & $\begin{array}{c}\mathrm{Nr} A n . \\
\text { albitarsis }\end{array}$ & $\begin{array}{l}\mathrm{Nr} A n . \\
\text { darlingi }\end{array}$ & $\begin{array}{c}\mathrm{Nr} \text { An. } \\
\text { nuneztovari }\end{array}$ & $\begin{array}{l}\mathrm{Nr} A n . \\
\text { oswaldoi }\end{array}$ & Subtotal \\
\hline \multirow[t]{12}{*}{$\overline{1996}$} & May & 5 & 474.2 & 28.2 & 22.7 & 6.5 & 4 & 0 & 5 & 0 & \\
\hline & June & 5 & 541.2 & 27.1 & - & - & 2 & 4 & 3 & 0 & \\
\hline & July & 5 & 331.6 & 27.1 & 25.6 & 6 & 28 & 0 & 45 & 1 & \\
\hline & August $b$ & 0 & 208.2 & 28.2 & 27.5 & 6 & 0 & 0 & 0 & 0 & \\
\hline & September & 5 & 109.6 & 29.5 & 27.5 & 6 & 1 & 1 & 0 & 0 & \\
\hline & October & 5 & 12 & 30.2 & 27.6 & 6 & 7 & 0 & 0 & 0 & \\
\hline & November & 5 & 32.8 & 29.6 & 26 & 6 & 48 & 5 & 18 & 4 & \\
\hline & December & 5 & 9.4 & 29.8 & 26.1 & 5 & 55 & 6 & 28 & 2 & 1997 \\
\hline & January & 5 & 113.5 & 29.5 & 25.3 & 5 & 19 & 1 & 6 & 3 & \\
\hline & February & 5 & 129.7 & 28.3 & 25 & 6 & 0 & 0 & 0 & 0 & \\
\hline & March & 5 & 3.8 & 29.9 & - & - & 0 & 0 & 0 & 0 & \\
\hline & April & 5 & 52.6 & 29.6 & - & - & 0 & 0 & 0 & 0 & \\
\hline \multicolumn{2}{|c|}{ Subtotal } & 55 & & & & & 164 & 17 & 105 & 10 & 296 \\
\hline \multirow[t]{5}{*}{1997} & May & 5 & 203.9 & 28.5 & - & - & 0 & 0 & 0 & 0 & \\
\hline & June & 5 & 209.4 & 28.7 & - & - & 1 & 0 & 1 & 0 & \\
\hline & July & 5 & 217.4 & 28 & - & - & 0 & 0 & 0 & 0 & \\
\hline & August & 5 & 144.8 & 29.2 & - & - & 0 & 0 & 0 & 0 & \\
\hline & September & c 5 & 3.1 & 30.8 & - & - & 44 & 0 & 0 & 0 & \\
\hline \multicolumn{2}{|c|}{ Subtotal } & 25 & & & & & 45 & & 1 & & 46 \\
\hline \multicolumn{2}{|c|}{ Total $(\%)$} & 80 & & & & & $209(61)$ & $17(5)$ & $106(31)$ & $10(3)$ & 342 \\
\hline
\end{tabular}

Rainy season is April to November. Dry season is December to March; $a$ : 2 collectors, 30 min collections; $b$ : collections were negative in August 1996 because margins were flooded and, $c$ : were negative from October 1997 to April 1998 because of drought; - not determined 


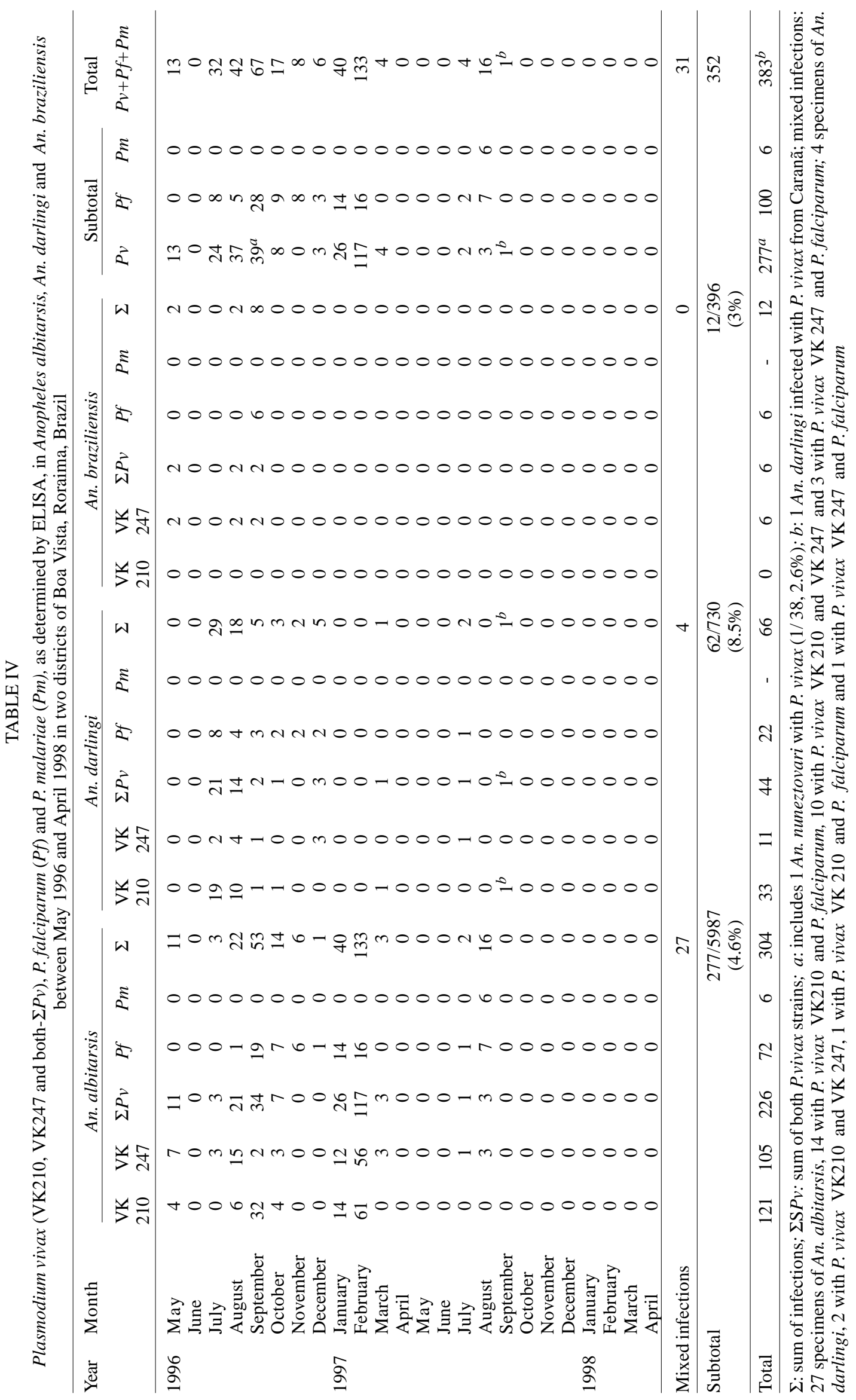




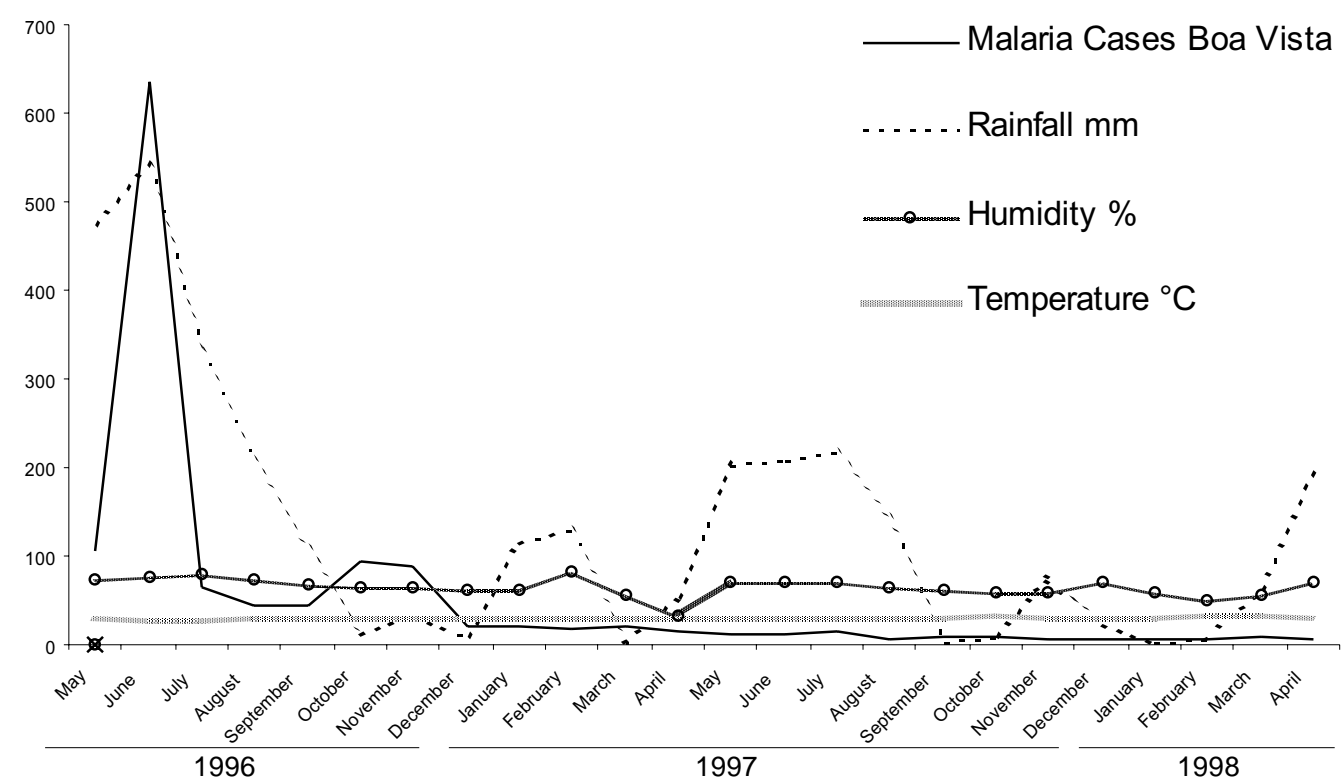

Fig. 4: malaria cases, rainfall, humidity and temperature indices for the period May 1996 through April 1998 in Boa Vista, Roraima

Meteorological variables, mosquitoes and malaria cases correlation - Mean monthly BI for An. albitarsis, An. darlingi, An. braziliensis were plotted against IR and EIR, rainfall, temperature, humidity and reported malaria cases for both 13 de Setembro and Caranã districts and, Boa Vista. P. malariae data for human malaria cases were not routinely diagnosed by health authorities.

Results showed that there was no significant correlation between meteorological variables tested (temperature, humidity and rainfall) and BI for 13 de Setembro $(\mathrm{r}<$ $0.4 \pm 0.21, p>0.05)$ or Caranã $(r<0.6 \pm 0.3, p>0.05)$.

There was no significant correlation between meteorological data (temperature, humidity and rainfall), IR and reported malaria cases for 13 de Setembro $(r<0.4 \pm 0.21$, $p$ $>0.05)$ and Caranã $(r<0.6 \pm 0.3, p>0.05)$. However, there was a positive significant correlation between rainfall and malaria cases for all Boa Vista $(r<0.65 \pm 0.21, \mathrm{p}<0.01)$.

\section{DISCUSSION}

A 2-year longitudinal entomological survey was conducted at two highly malaria endemic districts (13 de Setembro and Caranã districts, Fig. 2), of Boa Vista, Roraima, Brazil.

An. albitarsis, An. darlingi, An. braziliensis, An. peryassui and An. nuneztovari were collected at human bait. Morphological differences among most members of the albitarsis complex (Rosa-Freitas et al. 1990) were not defined. Random amplified polymorphic DNA (RAPD, Wilkerson et al. 1995) was not performed, therefore An. albitarsis refers to An. albitarsis sensu lato. An.albitarsis was the most common anopheline found throughout the period. Low numbers of An. darlingi were collected. In Boa Vista, the predominant savanna vegetation may account for this, since An. darlingi is often associated with low lying vegetation along forested river margins (Forattini 1962, Consoli \& Lourenço-de-Oliveira 1994, Rubio-Palis \& Zimmerman 1997).
Collections for the immature forms showed that the excavations made along the Branco River margins at 13 de Setembro for brick manufacturing contributed to adult anopheline populations. An. nuneztovari was the second most frequently collected species along the river margin (31\%), but was least frequently collected at human-bait $(0.6 \%)$. In this area, An. nuneztovari may be highly zoophilic and comparisons between bovine and human bait collections should be performed to confirm this. An. oswaldo $i$ was found only in its immature forms and not in human-bait collections. In some areas An. oswaldoi is highly anthropophilic, while in this site, it appears to prefer other animals. An. braziliensis and An. peryassui were collected only as adults and were not found in excavation pits as immatures.

BI and malaria reported cases showed no monthly correlation. Considering that the pre-patent period for $P$. vivax (the most prevalent species in Boa Vista) is 10-20 days (mean $\sim 12$ days at $24^{\circ} \mathrm{C}$, Garnham 1966) and considering that mosquito (infected) bites can increase in one month that would be registered (as disease) in the following month, statistical correlations of BI and IR means of a given month and malaria cases means of the next month were performed. Again, these variables showed no correlation perhaps due to small sample size an/or populations becoming infected elsewhere where BI and EIC were not measured.

BI varied considerably seasonally, hourly and by species. Among the selected environmental and biological parameters, there were significant differences for the rainfall and malaria indices $(0.65, \mathrm{p}<0.01)$ and, An. albitarsis infections and malaria indices $(0.62, \mathrm{p}<0.01$ for $P$. vivax and $0.47, \mathrm{p}<0.05$ for P. falciparum).

Host attraction activity demonstrates that while anophelines bite predominantly in the early evening (mainly at the first hour after sunset), small numbers continue to bite throughout the evening. Therefore malaria 


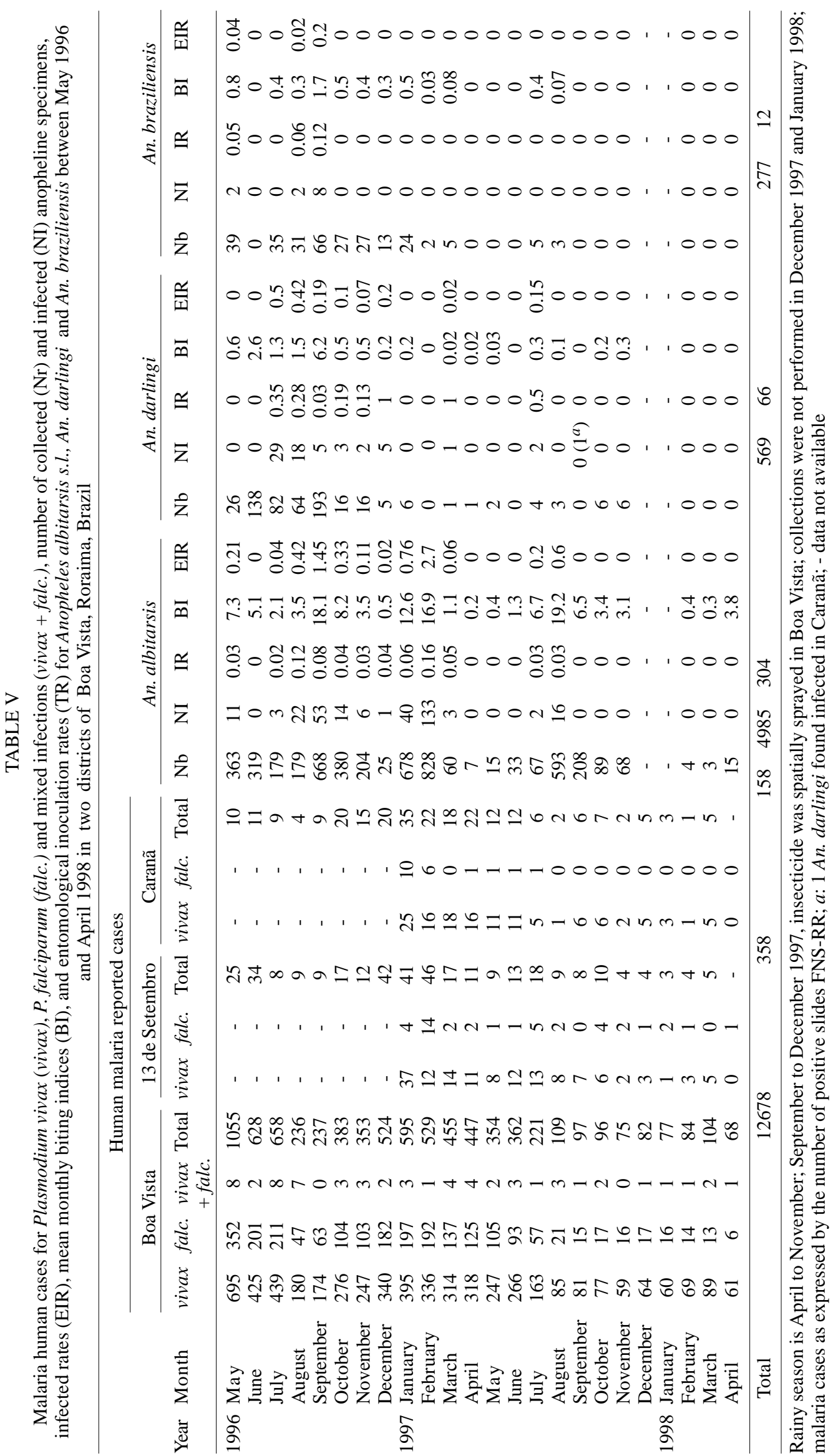


transmission may occur throughout the night, even though it is more likely to occur at sunset. The concomitant BI decrease for the period September-December 1996 and malaria cases observed could be due to a successful Malathion ultra-low volume pesticide fumigation program, aimed at Aedes aegypti reduction, due to a dengue outbreak in September 1996. Large decreases in rainfall indices could, on the other hand, account for the decrease of BI observed (Table V).

Rainfall indices appeared to affect the malaria rates. This has also been observed in Costa Marques, Rondônia, where increases in rainfall indices positively affected mosquito population numbers (Klein \& Lima 1990). During the long period of drought that extended from September 1997 to February 1998 in Boa Vista, there was a large decline in $\mathrm{BI}(<6.5$ thereafter for An. albitarsis and $<0.3$ for An. darlingi) and an associated low number of malaria cases. Between September 1997 and April 1998, the lowest rainfall indices in 20 years were observed (IBGE 1999). As a result, the water flow of the Branco and Cauamé rivers nearly halted. Large areas of vegetation were consumed by natural fires around Boa Vista, as well as other areas throughout the state. Not only mosquito immature populations might have been affected by the lack of suitable breeding habitats, adult populations might also have been reduced due to resting site reduction and the dry and smoky atmosphere prevailing in Boa Vista.

In contrast, during July and August 1997 rainfall indices were very high, $217.4 \mathrm{~mm}$ and $144.8 \mathrm{~mm}$, respectively. During that period, large areas of the city were flooded. During the extreme water levels, there was a corresponding decrease of malaria (135 to 63 cases, respectively) followed by an increase in the BI for An. albitarsis (6.7 to 19.2, July-August 1997) and a decrease in the An. darlingi BI (0.3 to 0.1, July-August 1997).

Biting indices for An. darlingi were generally low, suggesting a low participation of this species in the malaria transmission. However, even though low numbers of $A n$. darlingi specimens were collected, it had the highest combined infection rate (8.5\%). Deane (1986) stated that even though populations of An. darlingi were low, they significantly contribute to transmission due to its high susceptibility to Plasmodium parasites. Minimal biting indices could be enough for keeping the transmission cycle. In fact, the high IR observed in the period of July-December 1996, accounted for a steady EIR even with low BI (Table V). The second highest natural infection rate was observed for An. albitarsis (4.6\%). Even though presenting the second highest IR, An. albitarsis was the most frequently collected found species (82.8\%) and had the highest BI and EIR (Table V). An. albitarsis should be considered the primary malaria vector in Boa Vista due to its high density, high infection and potential transmission rates.

An. albitarsis s.l. has been recently assigned as a vector of primary importance in malaria transmission in Pará with IR of $4.5 \%$ (Arruda et al. 1986), Amapá with 1.6\% IR (Segura 1998) and 0.8\% IR (Póvoa et al. 2001) and, Rondônia, 0.5\% (Oliveira-Ferreira et al. 1990).

Malaria control is largely based on vector control. Usually, the moment to apply vector control measures is dic- tated by an outbreak of malaria cases and not before to prevent the outbreak. Nevertheless, as our results indicate, mosquito populations could have been decreased when malaria becomes "visible" through the diagnosis of cases. This would decrease the effectiveness of insecticide-based vector control methods. Therefore, vectorbased malaria control programs should rely on mosquito data, such as natural infection and biting rates rather than reported malaria cases.

Even though the importance of an integrated and decentralized approach to the malaria control program has been recognized in the last few years, little malaria control has been achieved as shown by the increasing numbers of malaria cases in Brazil and approximately 500 thousand cases have been reported annually over the last years.

Even with occurrences of torrential rain (in the period May-July 1996), drought (September-October 1997 and January-February 1998), insecticide fumigation application (September-December 1996), low mosquito BI for the two most frequent species, malaria cases did not subside in Boa Vista.

Statistical results indicated that malaria cases are not linked to mosquito BI, even though mosquitoes were found infected in the two most malarigeneous districts of Boa Vista. This might demonstrate that imported malaria cases from other municipalities may play a putative role on the maintenance of the endemicity in Boa Vista, that deserve to be better investigated. Roraima has localities of high API (as for the municipality of Mucajaí in 1999 with an API of 600, Funasa 2000). People transit intensively from Boa Vista towards those localities, and viceversa. Farmers and weekenders lead this transit. This intense flow of people can be a large contributor for the malaria maintenance in the capital and in the rest of the state.

The correct appreciation of the variables that compose the malaria panorama in a given area is critical. These variables can play distinct roles in different endemic areas. Important components of the control effort have been appointed in the past. They were related to better housing, that decrease the man vector contact and increase residual insecticide activity, the determination of the case origins, society engagement and, early diagnosis and treatment of the malaria cases (Botelho et al. 1986, Sawyer 1986, Motta 1992, Barata 1995, Marques 1995, Voorham 1997). We suggest that measures that could decrease people flow could play a putative role in malaria control and should be considered in the infrastructure of any government settlement programs. Among those measures, the availability of health care in the interior, farming supplies and equipments as well as produce cooperatives. To those variables related to vector biology, population fluctuation and natural infection of malaria vector species should be inserted in the routine of the entomological control teams. Entomological studies should include detailed taxonomy of vectors, monthly BI and natural infection determination to better assess the correct intervention time for larvicide and adulticide application. Routinely assessed mosquito BI and natural infection rates should allow health authorities to draw a threshold level. Larvicide and adulticide control measures should be under- 
taken every time this threshold level is reached. Success on vector control can be achieved when intervention times coincide with that of a low-high borderline mosquito populations. Then larval and adult control might prevent mosquito populations to increase. On the other hand, lack of correlation between reported malaria cases and biting indices may indicate that malaria is acquired elsewhere. In Roraima, human population daily flow movements from the interior to the capital Boa Vista and vice-versa could be of great importance to the malaria persistence. Cooperation teams working on entomology, protozoology, human ecology and, developmental infrastructure for a better quality of life will provide the tools to control malaria in the Amazon.

\section{ACKNOWLEDGEMENTS}

To Fernando Antonio Menezes da Silva, Director of the Centro de Ciências Biológicas e da Saúde (currently Chancelor of the Universidade Federal de Roraima), for his strong commitment to the installation of the Núcleo Avançado de Vetores; Hiran Manoel Gonçalves, Funasa Coordinator for support in transport and personnel to the field collections; Funasa entomologists; Antonio Bellini, Secretaria de Estado de Saúde de Roraima for support to disseminating our results in a meeting; to two anonymous referees for their invaluable contribution.

\section{REFERENCES}

Arruda M, Carvalho MB, Nussenzweig RS, Maracic M, Ferreira AW, Cochrane AH 1986. Potential vectors of malaria and their different susceptibility to Plasmodium falciparum and Plasmodium vivax in Northern Brazil identified by immunoassay. Am J Trop Med Hyg 35: 873-881.

Barata RC 1995. Malária no Brasil: panorama epidemiológico na última década. Cad Saúde Públ 11: 128-136.

Botelho C, Barbosa LSG, Silva MD, Meirelles SMP 1986. Fluxo migratório de casos de malária em Cuiabá, Mato Grosso. Rev Inst Med Trop São Paulo 30: 212-220.

Consoli RA, Lourenço-de-Oliveira R 1994. Classificação e principais espécies de importância sanitária. In RA Consoli, R Lourenço-de-Oliveira (eds), Principais Mosquitos de Importância Sanitária no Brasil, Fiocruz, Rio de Janeiro, p. 17-92.

Deane LM 1986. Malaria vectors in Brazil. Mem Inst Oswaldo Cruz 81 (Suppl. II): 5-14.

Forattini OP 1962. Tribo Anophelini. In OP Forattini, Entomologia Médica, Faculdade de Higiene e Saúde Pública, São Paulo, p. 303-503.

FNS-Fundação Nacional de Saúde/Sesau/Semsa. 1996. Relatório de epidemiologia, Roraima.

FNS-Fundação Nacional de Saúde/Sesau/Semsa. 1997. Relatório de epidemiologia, Roraima.

FNS-Fundação Nacional de Saúde/Sesau/Semsa. 1998. Relatório de epidemiologia, Roraima.

Funasa-Fundação Nacional de Saúde 2000. http:// www.funasa.gov.br/ epi/malaria/pdfs/plano_estaduais. pdf

Garnham PCC 1966. Malaria Parasites and Other Haemosporidia, Blackwell, Oxford, $1114 \mathrm{pp}$.

IBGE-Instituto Brasileiro de Geografia e Estatística 1996. http:/ / www.ibge. gov.br

Klein TA, Lima JBP 1990. Seasonal distribution and biting patterns of Anopheles mosquitoes in Costa Marques, Rondônia, Brazil. J Am Mosq Control Assoc 6: 700-707.

Marques AC 1995. Dados epidemiológicos de malária em todo o
Brasil, referentes a 1993. Rev Soc Bras Med Trop 28: 141-155. Motta EGF 1992. Fatores determinantes da situação da malária na Amazônia. Rev Soc Bras Med Trop 25 (Supl.II): 27-32.

NASA-National Aeronautics and Space Administration 2001. http://eosweb.larc. nasa.gov/sse

Oliveira-Ferreira J, Oliveira LR, Teva A, Deane LM, DanielRibeiro CT 1990. Natural malaria infections in anophelines in Rondônia state, Brazilian Amazon. Am J Trop Med Hyg 43: 6-10.

Póvoa MM, Wirtz RA, Lacerda RNL, Miles MA, Warlhurst DC 2001. Malaria vectors in the municipality of Serra do Navio, State of Amapá, Amazon Region, Brazil. Mem Inst.Oswaldo Cruz 96: 179-184.

Rodrigues PC 1993. Bioestatística, $2^{\text {a }}$ ed., Eduff, Niterói, RJ, 268 pp.

Rosa-Freitas MG, Deane L, Momen H 1990. A morphological, behavioral and isoenzymatic study in Anopheles albitarsis from 10 populations. Mem Inst Oswaldo Cruz 85: 275-289.

Rubio-Palis Y, Zimmerman RH 1997. Classificação eco-regional de vetores de malária nos trópicos. In Implementação do Controle Seletivo de Vetores da Malária na Região Amazônica, Fundação Nacional de Saúde, Brasília, p. 9-28.

Sawyer D 1986. The potential contribution of social research to control of malaria in Brazil. Mem Inst Oswaldo Cruz 81(Suppl. II): 31-37.

Schmidt JCJ 1942. O clima da Amazônia. Rev Bras Geog 4: 465500.

Segura MNO 1998. Estudo do Anopheles (Nys) darlingi Root 1926 e Anopheles albitarsis Arribálzaga 1878 (Diptera: Culicidae) como Vetores de Malaria numa Mesma Área de Transmissão e, Caracterização de Espécies do Complexo Albitarsis, MSc Thesis, Universidade Federal do Pará, Belém, $152 \mathrm{pp}$.

Shiff CJ, Minjas JN, Hall T, Hunt RH, Lyimo S, Davis JR 1995. Malaria infection potential of anopheline mosquitoes sampled by light trapping indoors in coastal Tanzanian villages. Med Vet Entomol 9:256-62.

Silva ELS 1993. Inventário Preliminar das Espécies Arbóreas das Florestas dos Arredores de Boa Vista (Roraima), uma Abordagem Fitossociológica. MSc Thesis, Inpa, Fundação Universidade do Amazonas, Manaus, 102 pp.

Voorham J 1997. Sobreposição do comportamento humano e anofélico em relação às atividades de controle vetorial nas Américas. In Implementação do Controle Seletivo de Vetores da Malária na Região Amazônica, Fundação Nacional de Saúde, Brasília, p. 49-54.

Wilkerson RC, Parsons TJ, Klein TA, Gaffigan TV, Bergo E, Consolim J 1995. Diagnosis by random amplified polymorphic DNA polymerase chain reaction of four cryptic species related to Anopheles (Nyssorhynchus) albitarsis - (Diptera: Culicidae) from Paraguay, Argentina and Brazil. J Med Entomol 32: 697-704.

Wirtz RA, Burkot TR, Graves PM, André RG 1987a. Field evaluation of enzyme-linked immunosorbent assays for Plasmodium falciparum and Plasmodium vivax sporozoites in mosquitoes (Diptera: Culicidae) in Papua New Guinea. $J$ Med Entomol 24: 433- 437.

Wirtz RA, Zavala F, Charoenvit Y, Campbell GH, Burkot TR, Schneider I, Esser KM, Beaudoin RL, André RG 1987b. Comparative testing of monoclonal antibodies against Plasmodium falciparum sporozoites for ELISA development. Bull WHO 65: 39-45.

WHO-World Health Organization 1991. Report of the meeting Prospects for malaria control by genetic manipulation of its vectors. TDR/BCV/MAL-ENT/91.3. 
Malaria and Mosquitoes in Roraima • Adenildo da Silva-Vasconcelos et al. 